\title{
GENDER DIMENSIONS OF VOCATIONAL INTEREST Amongst School Children In Tribal AREAS: A STUDY OF KINNAUR DisTRICT OF HiMACHAL PRADESH
}

\section{Shalini Gautam,Vineet Kumar Sharma andKrishan Kumar}

Vocational education is as important as traditional education. With the rising population and rapidly growing unemployment problems in the country, it has become essential to impart vocational education from school itself. It will cater to the future needs of skilled manpower requirements of the technological advanced society. Moreover, it is the need of the hour to shift traditional educational system to diversified education system. The state of Himachal Pradesh has emerged as a leader in the field of literacy and vocational development in recent times. The farm and non-farm economic activities have shown excellent growth in this hilly state. In this study, efforts have been made to find out the gender dimensions of vocational interests amongst school children of tribal Kinnaur district of Himachal Pradesh. The investigation showed significant values for the vocational interests of tribal boys and girls for agriculture, executive and household activities. The gender dimensions were observed to play an important role in the vocational interests. There is a strong need to provide vocational guidance at school level by introducing vocational education in the schools itself. It is of specific importance to the tribal areas which have already shown potential for inclusive developmental modules at household level.

KEYWORDS: Vocational Interest, Gender Dimensions, Tribal Areas, Kinnaur District

\footnotetext{
Shalini Gautam $\bowtie$

Research Scholar, Department of Education, H.P. University, Shimla, Himachal Pradesh, India Email:shalini.joshi704@gmail.com

Vineet Kumar Sharma

Counsellor IGNOU / Researcher, Department of Public Administration, H.P. University, Shimla, Himachal Pradesh, India

Email:vineetamish@gmail.com

Krishan Kumar

Professor, Department of Business Management, Dr Y S Parmar University of Horticulture and Forestry, Solan, Himachal Pradesh, India

Email:kksharma2021@gmail.com
} 


\section{INTRODUCTION}

Education plays a crucial role in the development of a particular society or region. It is related to social, political, economical, vocational, philosophical and cultural aspects of life. It imparts knowledge, skill and attitude needed by persons to work more efficiently in their own areas of competence. Vocational education prepares human beings to shoulder the responsibilities and avail the opportunities aimed at the achievement of a secure livelihood. The term vocation, as advocated by Deighton (1971), is reserved for the occupation chosen and engaged in for a substantial period of time because it is appropriate to the individual's ability, interests, value derives, personality and achievement motivation. Vocation according to Super (1983) is an activity pursued for its own shape with an objective other than monarchy gain, although it may incidentally result in gain. Vocation has been regarded as an integral aspect of human life. Life is considered incomplete without any vocation. The foundation for vocation should be laid when one is receiving education. It is so stated here that one of the main aims of education is to give maximum help in one's professional life.

India is referred to as a 'Young Nation' with 28 million population of youth being added every year. Only about 2.5 million vocational training seats are available in the country, whereas about 12.8 million persons enter the labour market every year. About 90 per cent of employment opportunities require vocational skills, something that is not being imparted on a large scale in schools and colleges. Ashwathi (2013) argued that the major reforms are needed for bringing about necessary 'flexibility' in the offering of vocational courses and development of 'modular competency based curricula' in collaboration with industry to suit the needs of both target groups and the employers (industry). This will be useful in reducing the shortage of skilled manpower.

Mujumdar (2011) has advocated for SSC (vocational) or its equivalent 10th grade certification in vocational stream on similar lines as HSC (vocational) at both national and state levels. Vocational Stream is required to be introduced at 8th grade through Bivalent Schools which may provide both conventional and vocational streams of education at secondary level. Presently, in India only sporadic courses as electives are being offered to students under bifocal scheme. However, a separate vocational stream offered by means of bivalent schools does not exist. The general trend reveals that employers prefer students with general education skills in addition to vocational skills. Thus, in all schemes related to SSC (Vocational) general educational courses should be emphasized e.g. problem solving, English, soft skills, business management etc. 
The present study refers to the tribal areas of the state of Himachal Pradesh consist of Kinnaur and Lahaul-Spiti districts along with Bharmour and Pangi sub-division of Chamba district. The inhabitants traditionally depend upon integrated farming systems comprising of tree crop and animal components for sustained livelihoods (Anonymous, 2012). The vocational education has special significance due to traditional agro-vocational and non-farm sector based livelihood opportunities and life support systems. The social cohesiveness and joint family system addresses the needs for minimum externally aided developmental modules and emphasis for local generation of employment and income avenues. The government is also emphasising on improved crop productivity and introduction of fruits and vegetables as farming entrepreneurs. There are assured returns from commercial farming and in this process many vocational interests are fast emerging which needs to be properly addressed through awareness programmes amongst school children. This will help them in making judicious decisions about their future endeavours. The present study was, therefore, conducted in district Kinnaur representing tribal area of Himachal Pradesh

\section{REVIEW OF RELATED LITERATURE}

Vocational interests play an important role in the life of an individual as these determine what one will do and how well he will do it. It refers to a variety of choices which an individual makes with respect to activities in which he is engaged (Mattoo, 2011). It is an admitted fact that an individual shows preference for one and aversion for another. It is the sum total of many interests that bear in any way upon an occupational career (Strong, 1954). While research shows conflicting evidence rejecting the relationship between vocational interest and personality variables, one of the most successful and influential theories describing the relationship between vocational interests and personality has been the theory of vocational personalities and work environments by Holland (1973). Arnold (2004) describes Holland's theory of vocational choice as being a dominant force in vocational psychology and career guidance. Holland gives types which resemble their vocational interests, namely Realistic, Investigative, Artistic, Social, Enterprising and Conventional (RIASEC).

Chander (1987) conducted a study to investigate educational and vocational interest of tribal high school students of Himachal Pradesh and found these to be significantly related to intelligence, socio-economic status and educational achievement. A critical study made by Javed and Abdul (1990) with regard to the vocational interests of the students of arts, science and commerce revealed that rural students were not interested in agriculture related vocations. Das (1991) studied the educational and vocational aspiration level of tribal and non tribal youths. The study pointed out that there was a 
significant difference between the educational aspirations of non scheduled tribe and scheduled tribe students at 0.01 level of probability. Sharma (1991) explored educational and vocational interests of tribal high school students. The results yielded that tribal female adolescents exhibited higher level of educational interest than tribal male counterparts in case of agriculture, fine arts, home science, humanities and science. But in the area of technology, tribal male students showed more educational interest than tribal female students. As regarding vocational interests are concerned, tribal female students were found to have higher level in constructive, artistic, agriculture, persuasive and household sectors.

\section{OBJECTIVES}

The following were specific objectives of the present study:

1. To study the vocational interests of selected tribal boys and girls.

2. To suggest policy issues for improved vocational entrepreneurship.

\section{HYPOTHESES}

Different hypotheses were formulated for testing the difference between vocational interests of boys and girls. These hypotheses were helpful in establishing the significant differences, if any, between the boys and girls suggesting thereby different policy interventions aimed at the vocationalization of school education. The specific hypotheses were as follows:

i. H0 : There is no significant difference between boys and girls of IX grade in their vocational interests.

ii. H1 : There is a significant difference between the boys and girls of IX grade in their vocational interests.

\section{METHODOLOGY}

Field surveys were conducted and data was collected on pretested schedules and questionnaires prepared specifically for the present study. Personal interview method was adopted for the collection of data. Interviews with key respondents were also conducted. Focus group discussions were also made with teachers, parents and representatives of the local administrative institutions to have better understanding about the potential vocational entrepreneurship. The secondary data was collected from government publications, bulletins, books, reports and other relevant documents. The collected data was statistically analyzed through the use of means and standard deviation. The reference year of data collection was 2008-09. A statistical test i.e. t-test was used for assessing the statistical significance of the 
difference in mean values. Simple tabular analysis was followed for the interpretation of the findings.

\section{SAMPLE}

A sample size of 100 students of IX grade was selected for the present study. Field investigations were conducted in different schools of Kinnaur district of Himachal Pradesh. Three schools from Kinnaur district were randomly selected (Table 1). These selected schools were located in rural areas of the district. Gender wise representation was given during the selection of final sample.

\section{Table 1}

Gender wise details of sample in Kinnaur district (Tribal Area).

\begin{tabular}{|l|l|c|c|c|}
\hline \multirow{2}{*}{ S.No. } & \multicolumn{1}{|c|}{ Name of the School } & \multicolumn{2}{|c|}{ Respondents } & \multirow{2}{*}{ Total } \\
\cline { 3 - 4 } & & Boys & Girls & \\
\hline 1. & Govt. Sr. Sec. School, Kalpa & 15 & 15 & 30 \\
\hline 2. & Govt. Sr. Sec. School, Reckong Peo & 18 & 22 & 40 \\
\hline 3. & Project Sr. Sec. School, Bhabanagar & 17 & 13 & 30 \\
\hline & Total & $\mathbf{5 0}$ & $\mathbf{5 0}$ & $\mathbf{1 0 0}$ \\
\hline
\end{tabular}

\section{TOOL UsED}

Vocational Interest Record (Bansal \& Shrivastva, 1998) was used for data collection in which there are 8 vocational interest areas (Agriculture, Artistic, Commercial, Executive, Household, Literary, Science and Social), each consisting of 16 items making a total of 128 items. ' 1 ' mark was assigned to every right mark response and the total number of scores were counted for each of the interest areas both vertically and horizontally. The reliability coefficient of Vocational Interest Record by test- retest method is given in Table 2. The validation criteria used for this test was to correlate the scores for the Vocational Interest Record with the teacher's rating. The coefficients of correlation are also presented in Table 2 . 
Table 2

Reliability Coefficients and Correlation Coefficients of Vocational Interests Amongst Selected Students.

\begin{tabular}{|l|c|c|}
\hline Area of Vocation & $\begin{array}{c}\text { Reliability } \\
\text { Coefficient }\end{array}$ & $\begin{array}{c}\text { Correlation } \\
\text { Coefficient }\end{array}$ \\
\hline Agriculture & 0.84 & 0.55 \\
\hline Artistic & 0.80 & 0.60 \\
\hline Commercial & 0.83 & 0.57 \\
\hline Executive & 0.72 & 0.60 \\
\hline Household & 0.76 & 0.72 \\
\hline Literary & 0.74 & 0.60 \\
\hline Science & 0.73 & 0.58 \\
\hline Social & 0.81 & 0.62 \\
\hline
\end{tabular}

\section{DATA COLLECTION}

To ensure the best possible conditions for administering the questionnaire, the teachers of selected schools were contacted and their cooperation was sought by emphasizing the objective and utility of the research project. The questionnaires were given to the students of class IX and were asked to give scores. The test consisted of 8 rows and 8 columns of interest areas. In each of these 64 boxes there was a pair of occupation and an individual student was asked simply to make his preference in each box. There was no time limit for the test. Suitable statistical tools i.e. mean, standard deviation and standard error were used to ascertain the nature of distribution of the scores on vocational interests. The hypothesis was tested through t-ratios.

\section{RESUlTS AND Discussion}

The details of the research findings are as follows:

Gender Dimensions of Vocational Interests between Tribal Boys and Girls

The sample respondents were studied to identify the gender approach towards the vocational interests of IX grade students for different vocational options. The data to prove the hypothesis that there is no significant difference between boys and girls of IX grade students for vocational interest was calculated on the basis of mean, standard deviation, standard error and t-ratio and is presented in Table 3. 
Table 3

Significance of Difference in Mean Scores of Girls and Boys of IX Grade for Different Areas of Vocational Interests.

\begin{tabular}{|c|c|c|c|c|c|}
\hline Variables & Groups & Mean & $\begin{array}{l}\text { Standard } \\
\text { deviation }\end{array}$ & $\begin{array}{c}\text { Standard } \\
\text { error }\end{array}$ & $t$ \\
\hline \multirow[t]{2}{*}{ Agriculture } & Boys (50) & 7.06 & 2.49 & 0.35 & \multirow[t]{2}{*}{$4.71^{*}$} \\
\hline & Girls (50) & 4.84 & 2.23 & 0.31 & \\
\hline \multirow[t]{2}{*}{ Artistic } & Boys (50) & 7.00 & 3.16 & 0.45 & \multirow[t]{2}{*}{1.39} \\
\hline & Girls (50) & 7.90 & 3.32 & 0.47 & \\
\hline \multirow[t]{2}{*}{ Commercial } & Boys (50) & 6.28 & 2.19 & 0.31 & \multirow[t]{2}{*}{0.66} \\
\hline & Girls (50) & 6.00 & 2.06 & 0.29 & \\
\hline \multirow[t]{2}{*}{ Executive } & Boys (50) & 8.66 & 2.12 & 0.30 & \multirow[t]{2}{*}{$2.76^{*}$} \\
\hline & Girls (50) & 7.62 & 1.61 & 0.23 & \\
\hline \multirow[t]{2}{*}{ Household } & Boys (50) & 6.00 & 1.94 & 0.27 & \multirow[t]{2}{*}{$5.60^{*}$} \\
\hline & Girls (50) & 8.16 & 1.92 & 0.27 & \\
\hline \multirow[t]{2}{*}{ Literary } & Boys (50) & 7.08 & 2.67 & 0.38 & \multirow[t]{2}{*}{1.61} \\
\hline & Girls (50) & 6.32 & 2.00 & 0.28 & \\
\hline \multirow[t]{2}{*}{ Science } & Boys (50) & 10.02 & 2.76 & 0.39 & \multirow[t]{2}{*}{0.89} \\
\hline & Girls (50) & 9.56 & 2.42 & 0.34 & \\
\hline \multirow[t]{2}{*}{ Social } & Boys (50) & 10.34 & 2.27 & 0.32 & \multirow[t]{2}{*}{1.33} \\
\hline & Girls (50) & 9.76 & 2.08 & 0.29 & \\
\hline
\end{tabular}

*Significant at 0.05 and 0.01 level of significance Figures in brackets represent total sample.

The findings show that the t-ratios between mean scores were statistically significant for the vocational interests of agriculture, executive and household. The statistical significance was established at 0.05 and 0.01 levels of significance. However, non-significant ratios were found for the vocational interests for artistic, commercial, literary, science and social aspects both for the tribal and non-tribal boys and girls. It, therefore, shows that there was significant difference between the mean scores of tribal boys and girls of IX grade on vocational interest areas of agriculture, executive and household. Similarly, it can also be concluded that the difference between the means scores of selected boys and girls for artistic, commercial, literary, science and social aspects was not significant. Therefore, research hypothesis that there is no significant difference amongst IX grade students for vocational interests is accepted for artistic, commercial, literary, science and social, however, the hypothesis stands rejected for agriculture, executive and household as there exists significant difference between boys and girls of IX grade on different areas of vocational interests. 


\section{RECOMMENDATIONS}

During focus group discussions and semi-structured interviews with key respondents like school teachers and experienced career counsellors, it was found that agriculture was the most prioritized vocational interest for the boys. Executive vocational enterprise has also attracted more number of males due to excellent working conditions of the national and multinational corporate houses. The conventional trend of traditional subjects like arts, literary, science and social science has attracted all the students irrespective of their gender. These subjects have still not lost their attraction due to possible entry into the government jobs equally preferred by both the genders of the society.

There is a need for the strengthening of vocational education in tribal areas of Himachal Pradesh. The introduction of vocational education at secondary level through bivalent schools and SSC (vocational) will enable us to broaden the vocational education base at secondary level of education. There is a strong need to provide vocational guidance at school level by introducing vocational education in the schools itself. Besides, framing of vocational qualification framework, introduction of vocational degrees and setting up of a Vocational University with Polytechnics, Community colleges, CPs and other VEPs as affiliated colleges are some of the recommendations which require further deliberation at National and State level.

\section{CONCLUSION}

The findings of the study drawn by statistical analysis of the collected data clearly points out towards significant differences in vocational interests of boys and girls for agriculture, executive and household in tribal areas. Further, it has been observed that the gender dimensions play an important role in the vocational interests of students. It is of specific importance to the tribal areas which have already shown potential for inclusive developmental modules at household level. It will help in developing abilities and capacities as per the interests of the students. The teachers may provide proper guidance and counselling for right selection of their vocational trade. It is recommended that a comprehensive study can be done by taking environmental factors like family traits, culture, teacher influence, etc. and psychological factors like intelligence, academic achievement, level of aspiration, values, etc. which play a pivotal role in affecting vocational interests of the students.

\section{REFERENCES}

Anonymous (2012). Statistical Abstract of Himachal Pradesh. Directorate of Economics and Statistics, Govt. of Himachal Pradesh.

Arnold, J. (2004). The congruence problem in John Holland's theory of 
vocational decisions. Journal of Occupational and Organizational Psychology. England - The British Psychological Society.

Ashwathi. (2013). A need to strengthen vocational education programmes. Retrieved August 17, 2013 from http:/ / education.oneindia.in /news/ 2013/06/25/.

Bansal, B.P., \& Shrivastva, D.N. (1998). Manual for vocational interest record. Agra: National Psychology Corporation.

Bloye, E.J. (2007). Vocational interest and other non-cognitive factors as predictors of academic performance in high school. Unpublished. A minor dissertation of M.Sc. in Psychology, Johannesburg: University of Johannesburg.

Chander, P. (1987). A study of the educational and vocational interest patterns of tribal high school students and their relationship with intelligence, socio-economic status and educational achievement. Unpublished. Ph.D. thesis. Shimla, Himachal Pradesh University.

Das, D.G. (1991). A study of the educational and vocational aspiration levels of the south Gujarat region- A cultural study. In Fifth Survey of Educational Research (1988-92) NCERT: New Delhi.

Deighton, L.C. (1971). Encyclopaedia of educational research (Vol.11). USA: The MacMillan Company and The Free Press.

Holland, J.L. (1973). Making vocational choices: A theory of careers. Englewood Cliffs, NJ: Prentice Hall.

Javed., \& Kureshi, A. (1990). A critical study of the vocational interests of the students of arts, science and commerce studying at graduation level in senior colleges in the rural areas. In Fifth Survey of Educational Research (1988-92), NCERT, New Delhi.

Mattoo, M.I. (2011). Vocational interests and academic achievement of secondary school students at different levels of creative thinking ability- A comparative study. Indian Educational Review. Half Yearly Journal of Education Research. NCERT, New Delhi.

Mujumdar, S. (2011). Need for vocationalisation of education in India. Retrieved August 16, 2013 from http:/ / www.indiaeducation review.com.

Shalini. (2008). A comparative study of vocational interests among tribal and nontribal IX grade students in Himachal Pradesh. Unpublished. M.Ed. Dissertation. Shimla: Himachal Pradesh University.

Strong, E. (1954). Vocational Interests of Men and Women. Stanford: Stanford University Press.

Super, D.E. (1983). The history and development of vocational psychology: A personal perspective. In W.B. Walsh \& S.H. Osipow (Eds.), Handbook of vocational psychology. Hillsdale, NJ: Erlbaum. 